\title{
A review of the impact of mining operations on sustainable development
}

\author{
Ciprian Trocan ${ }^{1}$, Marian Mocan ${ }^{1}$, Lucian-Ionel Cioca ${ }^{2,3}$, Larisa Ivascu ${ }^{1,3,4^{*}}$, Rebeca \\ Ardelean $^{1}$ \\ ${ }^{1}$ Politehnica University of Timisoara, Faculty of Management in Production and Transportation, \\ 300191 Timisoara, 14 Remus Street, Romania \\ ${ }^{2}$ Lucian Blaga University of Sibiu, Faculty of Engineering, Department of Industrial Engineering and \\ Management, 550024 Sibiu, Romania \\ ${ }^{3}$ Department of Technical Sciences, Academy of Romanian Scientists, 010071 Bucharest, Romania \\ ${ }^{4}$ Research Center for Engineering and Management, Politehnica University of Timisoara, 300191 \\ Timisoara, Romania
}

\begin{abstract}
Global annual extraction has increased due to market demand. It is anticipated that this aspect will continue in the future. The mining industry is one of the important industries at national level. It also anticipates certain aspects of sustainability that must be seriously evaluated. The main objective of this paper is to evaluate mine waste reuse, pollution, and recycling in mining industries. At the same time, mining operations are evaluated to carry out a review of the implications for sustainability. In order to achieve the research aspects, a qualitative evaluation and a semi-quantitative evaluation of some data series are used. For the entire research approach, the objectives of sustainable development and its principles are used. At the same time, the results emphasize the importance of the existence of an efficient waste and pollution management.
\end{abstract}

\section{Introduction}

Sustainability has become a concern of more and more companies and industries. This is due to national and international activities. If at first sustainability was perceived as a concern for improving the image, now it has become an important concern for operational efficiency and improving environmental conditions. The demand for materials extraction increases as the world's population and economic activities grow and intensify. The global annual extraction has seen a considerable increase since 1970 and until now. There was a tripling of activity [1]. Non-metallic minerals are expected to grow significantly (especially when it comes to building materials: sand, gravel, and others). It emphasizes the advantages of the 4th industrial revolution that could know and develop new forms: the use of online meetings, tools for telework work and others $[2,3]$. Thus, the processes will be automated,

\footnotetext{
*Corresponding author: larisa.ivascu@upt.ro
} 
and robots and data centers will be a necessity. These elements require metals that contribute to the negative impact of the industry on the environment $[3,4]$.

The set of 17 objectives signed by the representatives of the 193 member states is the general global development framework. Companies in various industries set a number of goals that they want to achieve. Mining has an important contribution to the production of goods, services, and infrastructure. Radioactivity and waste are two important issues in this industry. Companies in the manufacturing industry target social, partnership and innovation objectives. Mining companies have the potential to become partners in achieving goals. Through their activities, mining companies can contribute to strengthening the social dimension by developing jobs. At the same time, they can generate profits, develop partnerships with the government and society and contribute to the development of a better life. Therefore, the mining industry can have a positive impact on the environment and the economy, but also on climate change $[5,6]$.

Mining companies are supported to extract with great responsibility, to use safe and innovative processes, to integrate sustainable technologies, to reduce emissions and the amount of waste, to support the well-being of society and to improve their capacity for environmental management. However, the significant mining impact on the environment is known and continues to be examined. Globally, several investments have been made in this industry, but the inherited negative image is often an obstacle. It is shown that $[7,8]$ over $80 \%$ of the world's largest companies in the extractive industry publish information on environmental, economic, and social performance [9].

This paper aims to assess the impact and implications of the mining industry on the objectives of sustainable development and reducing the footprint on the environment. At the end of the paper is a systematization of the main implications of this industry and a series of recommendations for improving the capacity for success and recycling, but also reducing the level of pollution.

\section{Mining and Sustainable development}

In this chapter, the mining implications in sustainable development are evaluated. The most important directions and implications are addressed. An evaluation is made of the direct and indirect impacts of the operations on the 17 sustainable development goals (SDG), then the implications of mine waste reuse, pollution, and recycling in mining industries are presented. These actions are the basis for the systematization of action directions for the development of an efficient waste and pollution management $[8,9]$.

\subsection{Mining and 17 SDGs}

Based on the implications of sustainability and the 17 SDGs, the following is an assessment of the implications of mining operations on them. It can be seen in Table 1 that mining operations can have a very direct, direct, moderately direct, or indirect impact on sustainability objectives. This evaluation was based on the literature and the experience of the authors [7-9].

Table 1. Mining and 17 SDGs.

\begin{tabular}{|c|c|c|}
\hline $\begin{array}{c}\text { Sustainable } \\
\text { Development Goals }\end{array}$ & Mining industry implication & Impact \\
\hline SDG 1 & $\begin{array}{c}\text { The mining industry generates a number of significant } \\
\text { revenues that have effects on various financial } \\
\text { statements. Develops jobs and offers decent working } \\
\text { conditions. }\end{array}$ & Indirect \\
\hline
\end{tabular}




\begin{tabular}{|c|c|c|}
\hline SDG 2 & $\begin{array}{l}\text { It offers jobs and connections can be made with the } \\
\text { agricultural sector. }\end{array}$ & Indirect \\
\hline SDG 3 & $\begin{array}{l}\text { It contributes to the development of the population's } \\
\text { well-being by creating jobs and by permanent training. }\end{array}$ & Moderately direct \\
\hline SDG 4 & $\begin{array}{l}\text { There is a level of training of employees in this } \\
\text { industry. At the same time, the industry is involved in } \\
\text { the permanent training of employees, being a field with } \\
\text { considerable risks. }\end{array}$ & Moderately direct \\
\hline SDG 5 & $\begin{array}{c}\begin{array}{c}\text { Mining reduces gender disparities and is based on a fair } \\
\text { approach. }\end{array}\end{array}$ & Indirect \\
\hline SDG 6 & $\begin{array}{l}\text { Mining has a direct impact on life on land because it } \\
\text { requires direct access to the ground. These activities } \\
\text { can have negative effects on life on land. }\end{array}$ & Very direct \\
\hline SDG 7 & $\begin{array}{l}\text { Supports energy efficiency and the development of } \\
\text { partnerships for the shared use of energy infrastructure }\end{array}$ & Very direct \\
\hline SDG 8 & $\begin{array}{c}\text { This industry can generate new job opportunities, } \\
\text { suppliers and quality services. }\end{array}$ & Very direct \\
\hline SDG 9 & $\begin{array}{l}\text { Supporting the creation of a more resilient } \\
\text { infrastructure }\end{array}$ & Very direct \\
\hline SDG 10 & $\begin{array}{l}\text { Encouraging the reduction of inequalities at the level of } \\
\text { the entity. }\end{array}$ & Moderately direct \\
\hline SDG 11 & $\begin{array}{l}\text { Provides raw materials for the development of } \\
\text { sustainable communities. }\end{array}$ & Indirect \\
\hline SDG 12 & $\begin{array}{l}\text { It exploits the soil and can have a considerable impact } \\
\text { on global sustainability. }\end{array}$ & Moderately direct \\
\hline SDG 13 & Combating climate change and its effects & Indirect \\
\hline SDG 14 & $\begin{array}{l}\text { Through the exploitation activities, the species that live } \\
\text { in the waters can be affected. }\end{array}$ & Indirect \\
\hline SDG 15 & $\begin{array}{l}\text { Mining involves direct access to land and water, and } \\
\text { these implications could be reduced by implementing } \\
\text { innovative technologies to streamline business. }\end{array}$ & Very direct \\
\hline SDG 16 & $\begin{array}{c}\text { Mining can develop peaceful activities and ensure } \\
\text { transparent reporting. }\end{array}$ & Moderately direct \\
\hline SDG 17 & $\begin{array}{c}\text { The mining industry supports the development of } \\
\text { strong partnerships. }\end{array}$ & Moderately direct \\
\hline
\end{tabular}

As highlighted in the previous table, the mining industry influences the objectives of sustainability and implicitly of the environment. These impacts of different levels can be reduced by implementing innovative activities and information technology $[12,13]$.

\subsection{Mine waste reuse, pollution, and recycling}

In the mining industry, radioactivity and waste are two important issues. Finding appropriate solutions for waste reuse and recycling could provide a cost-effective benefit. Monitoring pollution in this industry and developing strategies for mine deposit management are important requirements. Usually, waste generated by mining has no economic value. Waste storage around mine sites is an important issue [10,11].

From the perspective of final energy consumption, there has been no considerable change. The final energy consumption is defined as "It includes the quantities of primary and transformed energy carriers used in consumer installations, as a result of which no further energy processing or transformation takes place" [12]. 
Table 2. Final energy consumption in industry by domain activities.

\begin{tabular}{|c|c|c|c|c|c|}
\hline \multirow[b]{3}{*}{ Industry activities } & \multicolumn{5}{|c|}{ Years } \\
\hline & 2015 & 2016 & 2017 & 2018 & 2019 \\
\hline & $\begin{array}{c}\text { Thousands of } \\
\text { tons of oil } \\
\text { equivalent }\end{array}$ & $\begin{array}{c}\text { Thousands of } \\
\text { tons of oil } \\
\text { equivalent }\end{array}$ & $\begin{array}{c}\text { Thousands of } \\
\text { tons of oil } \\
\text { equivalent }\end{array}$ & $\begin{array}{c}\text { Thousands of } \\
\text { tons of oil } \\
\text { equivalent }\end{array}$ & $\begin{array}{c}\text { Thousands of } \\
\text { tons of oil } \\
\text { equivalent }\end{array}$ \\
\hline $\begin{array}{c}\text { Industry } \\
\text { (including } \\
\text { construction) }\end{array}$ & 6438 & 6301 & 6407 & 6619 & 6659 \\
\hline $\begin{array}{c}\text { Extraction of } \\
\text { metalliferous ores }\end{array}$ & 11 & 10 & 11 & 11 & 11 \\
\hline $\begin{array}{c}\text { Other extractive } \\
\text { activities }\end{array}$ & 26 & 28 & 30 & 28 & 27 \\
\hline
\end{tabular}

In accordance with Sustainability Reporting in the Mining Sector [5], the need for prevention, waste minimization, reuse and recycling are emphasized. This report also shows that some of the reuse and recycling concepts proposed for application are not economically efficient. Many of the mining wastes are placed in landfills and are not subject to sustainable activities [7,8]. Considerable research needs to be developed to develop meaningful options for this mining waste problem.

According to the National Institute of Statistics [12], the industrial waste generated by the main industries is presented in the following figure.

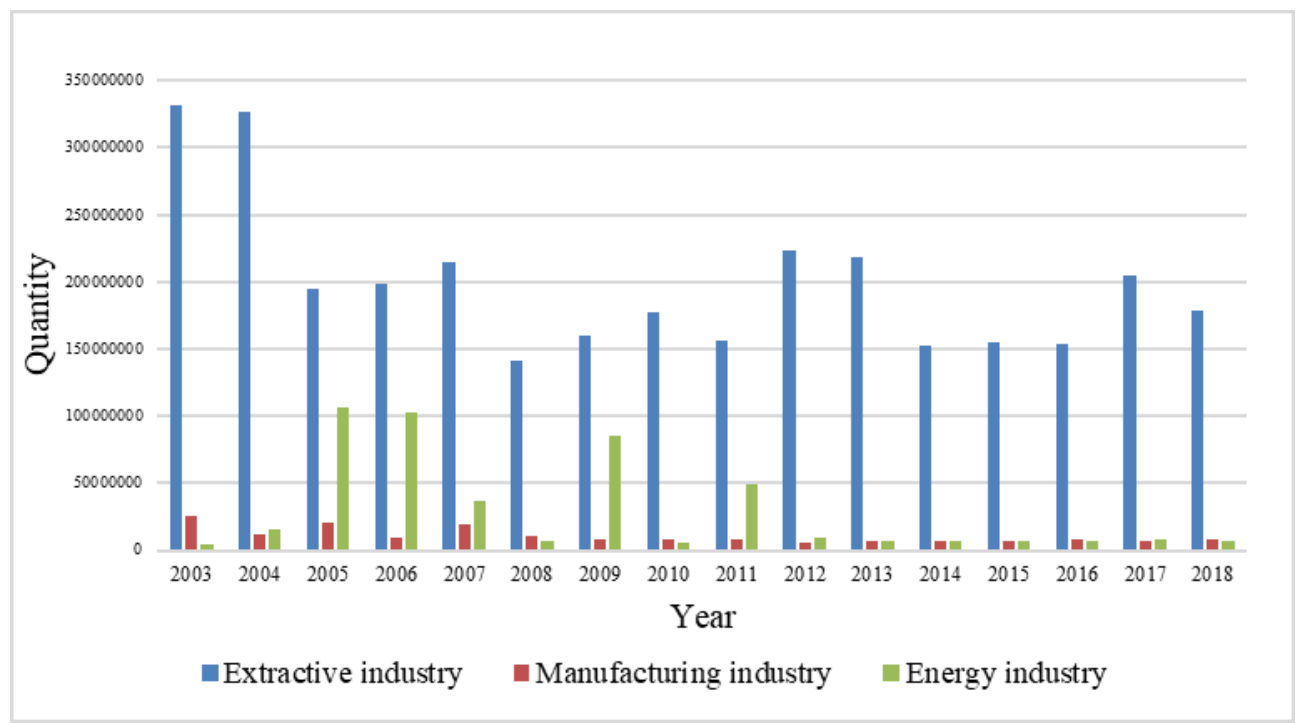

Fig 1. Industrial waste generated (tons) 
From the perspective of wastewater, it can be seen that the mining industry has a small percentage in the total volume of wastewater [12].

Table 3. Volume of wastewater

\begin{tabular}{|c|c|c|c|c|c|c|c|}
\hline \multirow{2}{*}{$\begin{array}{c}\text { Volume of } \\
\text { wastewater }\end{array}$} & \multirow{2}{*}{$\begin{array}{c}\text { Sectors } \\
\text { of } \\
\text { activity }\end{array}$} & \multirow{2}{*}{$\begin{array}{c}\text { Units of } \\
\text { measurement }\end{array}$} & \multicolumn{6}{|c|}{ Years } \\
\cline { 7 - 9 } & Total & $\begin{array}{c}\text { Million cubic } \\
\text { meters / year }\end{array}$ & 1942.75 & 1954.1 & 1885.13 & 1914.81 & 1896.28 \\
\hline $\begin{array}{c}\text { Volume of } \\
\text { wastewater }\end{array}$ & Mining & $\begin{array}{c}\text { Milioane } \\
\text { industry }\end{array}$ & & & & & \\
\hline & metri cubi/ an & 51.56 & 57.09 & 38.01 & 37.7 & 36.97 \\
\hline
\end{tabular}

Globally, the world production of precious metals from the year 2014-2018 shows an increase on most metals. This situation is presented in the following table [12]. From this situation we can see an increase in demand for precious metals due to market demand and user desires. As a result, these demands may conflict with the principles of sustainability.

Table 3. The world production of precious metals from the year 2014-2018

\begin{tabular}{|c|c|c|c|c|c|c|}
\hline Commodity & $\mathbf{2 0 1 4}$ & $\mathbf{2 0 1 5}$ & $\mathbf{2 0 1 6}$ & $\mathbf{2 0 1 7}$ & $\mathbf{2 0 1 8}$ & $\mathbf{2 0 1 9}$ \\
\hline Gold & 3027838 & 3120326 & 3257955 & 3337532 & 3367607 & 3379608 \\
\hline Palladium & 186555 & 206195 & 212129 & 204633 & 223497 & 227112 \\
\hline Platinum & 144721 & 190529 & 189542 & 184641 & 189110 & 190002 \\
\hline Rhodium & 17218 & 22964 & 23956 & 23074 & 22938 & 23010 \\
\hline Silver & 27301259 & 28020395 & 27952977 & 26794050 & 27698787 & 27998623 \\
\hline
\end{tabular}

\subsection{Mining Positioning}

Based on the previous analysis, a series of challenges can be structured that can appear in the mining industry from the perspective of sustainable development. Studies in the mining industry have gained important research in recent years. These studies have published a number of strategies that help solve environmental problems. The main problem is that mineral resources are finite and non-renewable. Based on the principles of sustainability, which states that future generations must have access to the same resources as current generations, these resources theoretically would not have the same intensity. Other studies show that dust, noise, surface and groundwater pollution and changes in exploited areas affect the well-being of society and have an effect on the environment $[6,7,8]$.

Existing studies [2-8] show that mines have been and are conservative in the application of new technologies. Automation is an important step for this industry. Automation contributes to the efficiency of operations, and the activity in the mine takes place continuously. This automation can be adapted to existing equipment without the need for major investments. He may know different forms that develop important benefit. Autonomous trucks are also a solution to streamline business and reduce environmental impact. Automatic drilling systems are important for sustainability and reduce downtime. 
Automatic monitoring, autonomous train ventilation systems and other solutions are among the investments that can help reduce the level of pollution.

Renewable energy, electrification, and digitalization are important directions for the mining industry and sustainability.

\section{Directions, discussion, and conclusions}

The mines have a long life, and the activity within them is intense. Based on the waste produced by this industry, the following options for recycling and reuse of waste can be considered. The fundamental problem is not the depletion of resources but the environmental risks that are developed from mining operations.

The main environmental problems facing the mining industry are:

- Technological and technical risks,

- The air pollution,

- The amount of greenhouse gas emissions,

- Increasing amount of energy required,

- The amount of waste generated,

- Lack of technology,

- Low adoption of renewable energy used,

- Innovative configurations for developed processes,

- Lack of automation in mining operations.

Table 4. Activities to reduce pollution, increase capacity for reuse and recycling.

\begin{tabular}{|l|l|l|}
\hline Type & Reuse and recycle activities & Pollution activities \\
\hline Mining wastes & $\begin{array}{l}\text { Digitization and automation are } \\
\text { important directions for reducing the } \\
\text { amount of waste. }\end{array}$ & $\begin{array}{l}\text { Reducing the amount of waste } \\
\text { contributes to reducing the level of } \\
\text { pollution. }\end{array}$ \\
\hline Processing wastes & $\begin{array}{l}\text { Automation is the main target globally. } \\
\text { Thus, the amount of waste can be } \\
\text { inherited considerably Automatic } \\
\text { machines follow the required protocols } \\
\text { compared to human resources, reducing } \\
\text { inefficient use. }\end{array}$ & $\begin{array}{l}\text { By automating the processes, the } \\
\text { pollution level and the duration of the } \\
\text { performed operations can be reduced. }\end{array}$ \\
\hline $\begin{array}{l}\text { Metallurgical } \\
\text { wastes }\end{array}$ & $\begin{array}{l}\text { Application of solvometallurgy for } \\
\text { several secondary resources. }\end{array}$ & $\begin{array}{l}\text { Automation and digitization of } \\
\text { activities to reduce the amount of } \\
\text { waste. }\end{array}$ \\
\hline
\end{tabular}

The mining industry must continuously enrich its approach, to increase its degree of transparency and communication. New approaches to sustainability involve the new innovative technologies that are needed in this industry as well. Overcoming existing barriers contributes to increasing the capacity of the industry for sustainable development.

\section{References}

1. E. Segerstedt, L. Abrahamsson, L., In Extractive Industries and Society, 6, 2 (2017).

2. K. Angelakoglou, G. Gaidajis, G., Sustainability, 12, 5, (2020)

3. L. Zeng, B. Wang, L. Fan, J. Wu, J., Resour. Policy, 49, (2016).

4. I. Harymawan, A. Ardianto, R.R. W.Ningtyas Soeprajitno, M.C. Ratri, Y.I. Paramitasari, Sustainability, 9, (2020).

5. A.A. Khan, W.A. Khan, A.A. Chaudhry, A.A., Pak. J. Zool., 47, 1205-1211 (2015)

6. N.A. Zaigham, Z.A. Nayyar, Z.A. Renew. Sustain. Energy Rev., 14 (2010) 
7. T. T. Phuong, R.P. Shrestha, H.V. Chuong, Simulation of soil erosion risk in the upstream area of Bo River watershed. In Redefining Diversity \& Dynamics of Natural Resources Management in Asia; Elsevier: Amsterdam, The Netherlands, 3, 87-99 (2017)

8. M. Dondini, M. Abdalla, F.K. Aini, F. Albanito, M. R. Beckert, K. Begum, A. Brand, K. Cheng, L. P. Comeau, E. O. Jones, Projecting soil $C$ under future climate and land-use scenarios (modeling). In Soil Carbon Storage; Elsevier: Amsterdam, The Netherlands, 281-309 (2018)

9. M. Sarfraz, S.G.M. Shah, L. Ivascu, M.A.A. Qureshi, Int. J. Finance Econom., (2020).

10. L. Ivascu, Processes, 8, 5, (2020).

11. S. Que, L. Wang, K. Awuah-Offei, Y. Chen, W. Yang, W., Sustainability, 10, 6, (2018).

12. http://statistici.insse.ro:8077/tempo-online/

13. https://www.world-mining-data.info [Accessed 10.07.2021]

14. https://www.unep.org/about-un-environment [Accessed 10.07.2021] 